\title{
MODEL DVOJEZIČNEGA POUKA V PREKMURJU IN SLOVAR KOT DIDAKTIČNI PRIPOMOČEK
}

\section{Jutka RUDA ̌}

Filozofska fakulteta Univerze v Mariboru

Maribor, Slovenija

\section{Anna KOLLÁTH}

Filozofska fakulteta Univerze v Mariboru Maribor, Slovenija

Rudaš, J., Kolláth, A. (2017): Model dvojezičnega pouka v Prekmurju in slovar kot didaktični pripomoček. Slovenščina 2.o, 2 (2017): 64-84.

DOI: http://dx.doi.org/10.4312/slo2.0.2017.2.64-84.

Model dvojezične vzgoje in izobraževanja sodi med dvosmerne modele ohranjanja dveh jezikov in kultur. V prvem delu prispevka predstavljamo uspešno uresničevanje dvojezičnega vzgojno-izobraževalnega procesa $\mathrm{v}$ Prekmurju s kratkim razvojnim lokom in izpostavimo najpomembnejše pogoje za njegovo izvajanje, vključno s podprtostjo izobraževanja učiteljev. Nato se posvetimo ključnim pomankljivostim modela: nedodelanosti didaktične plati dvojezičnega pouka in neustrezni usposobljenosti učiteljev dvojezičnih šol na tem območju. Ena najpomembnejših poti do učinkovite usvojitve (strokovno)jezikovne strukture in uporabe jezika so dvojezični učbeniki in drugi učni pripomočki. Pri rabi učnih pripomočkov gre za zahtevno in pomembno spretnost, zato je ključnega pomena, da se učitelji, pa tudi učenci, dodatno usposobijo za delo z njimi. Slovar kot didaktični pripomoček ni zgolj sredstvo za informiranje, ampak osnova za razvijanje spretnosti na različnih jezikovnih ravneh. Na podlagi teh ugotovitev v drugem delu prispevka najprej podajamo pregled obstoječih dvojezičnih madžarsko-slovenskih oz. slovensko-madžarskih slovarjev in ostalih učnih gradiv, nato pa predstavimo dva nedavna projekta, katerih cilji so usmerjeni v izdelavo dvojezičnih slovarjev, učnih gradiv in izboljševanje kompetenc učiteljev v dvojezičnih šolah v Prekmurju. V zaključku strnemo glavne ugotovitve in ponudimo razmisleke o naslednjih korakih za izboljšavo dvojezičnega modela izobraževanja. 
Ključne besede: dvojezično šolstvo v Prekmurju, dvojezični slovar, materni jezik, drugi jezik, jezikovne kompetence

\section{DVOJEZIČNO IZOBRAŽEVANJE}

V Prekmurju poteka izvajanje dvojezičnega izobraževanja od leta 1959. ${ }^{1}$ Delovanje, učinkovitost in uspešnost tega so od samih začetkov predmet velikega zanimanja tako stroke kot (izobraževalne) politike ter ne nazadnje neposrednih in posrednih deležnikov: učencev, staršev in učiteljev. $\mathrm{Na}$ narodnostno mešanem območju so bili do konca petdesetih let prejšnjega stoletja del izobraževalnega modela enojezični slovenski in enojezični madžarski oddelki. Ta model izobraževanja se je v marsičem pokazal kot slab, namreč, tisti, ki so končali madžarske oddelke, se niso mogli vpisovati v slovenske srednje šole zaradi pomanjkljivega znanja slovenskega jezika, zaradi železne zavese pa izobraževanja ni bilo mogoče nadaljevati na madžarskih srednjih šolah. Tako se enojezični oddelki v dvojezičnih skupnostih niso pokazali kot najboljši model, saj dijakom niso omogočali integracije v enojezičnih slovenskih srednjih šolah, kjer je pouk potekal v jeziku večine, dvojezične srednje šole pa takrat še ni bilo.

Zaradi maloštevilne (madžarske) skupnosti je bilo treba vpeljati drug model in sicer model dvojezičnega izobraževanja, o katerem se mnenja strokovnjakov še danes razlikujejo.

O dvojezičnem izobraževanju govorimo, če gre za obliko izobraževanja, katerega (poglavitni) cilj je, da učenci postanejo dvojezični. Dvojezično izobraževanje razpolaga $\mathrm{v}$ položaju manjšinske dvojezičnosti $\mathrm{z}$ večplastnim sistemom (Skutnabb-Kangas 1990, 1997). Taki dvojezični modeli so na primer kanadski imerzijski izobraževalni model (Quebec), retoromansko-nemški

\footnotetext{
${ }_{1}^{1}$ Toponim Prekmurje pomeni narodnostno mešano področje, opredeljeno v Ustavi Republike Slovenije in občinskih statutih in v Zakonu o posebnih pravicah italijanske in madžarske narodne skupnosti na področju vzgoje in izobraževanja (ZPIMVI). Dostopno: mss.gov.si.
} 
dvojezični (imerzijski) program (RDI) v Švici ter finski dvojezični model za finsko-švedsko govorečo populacijo (Kolláth 2013: 567-579). Zaradi velike razsežnosti, ki jo premore dvojezičnost, obstajajo številne opredelitve same dvojezičnosti, zato je nujno, da se pri definiciji konkretne oblike dvojezičnega izobraževanja pojasni, katera vrsta dvojezičnosti je zastavljeni cilj v Prekmurju. Namreč, ti cilji ne morejo biti identični za vse govorne skupine, temu primerno različni izobraževalni modeli pa zahtevajo različne faze načrtovanja izobraževalnega dela (Bartha 1999; Kolláth ur. 2009; Lanstyák 2005). Manjšinsko dvojezičnost vse pogosteje izpodriva dvojezičnost $\mathrm{z}$ dominanco materinščine, ki poudarja pomen usvojitve registra govorjenega drugega jezika na visoki ravni. Materni jezik je v izobraževalnem procesu pomembnejši tako $\mathrm{s}$ stališča komunikativne kot kognitivne funkcije, drugi jezik je načeloma le sredstvo za integracijo v večinsko družbo (Göncz 2004: 273). Dvojezično izobraževanje torej $\mathrm{v}$ položaju manjšinske dvojezičnosti razpolaga $\mathrm{z}$ večplastnim sistemom (Skutnabb-Kangas 1990, 1997; Kontra 1997; Bartha 2003; Lanstyák 2005). Konceptualno pojasnjevanje dvojezičnega izobraževanja in izobraževanja $\mathrm{v}$ dveh učnih jezikih predstavlja eno osrednjih vprašanj stroke. Definicije običajno vključujejo štiri stališča: opredeljene jezikovne cilje in standarde danega izobraževalnega modela, v učnem načrtu zastavljeni in načrtovani položaj dveh (učnih) jezikov, jezikovno homogenost in heterogenost izobraževalnega procesa ter položaj, ki ga zaseda določeni model izobraževanja v šolskem sistemu na državni ravni (Bartha 2004: 762).

\section{DVOJEZIČNI MODEL V PREKMURJU}

Do leta 1959 je izobraževanje prekmurskih Madžarov s stališča poučevanja materinščine in pouka $\mathrm{v}$ maternem jeziku potekalo po metodi, ki podpira segregacijo manjšine; učenci, ki so govorili jezik manjšine, so bili deležni posebnega izobraževanja $\mathrm{z}$ vključevanjem državnega jezika, in sicer $\mathrm{v}$ obliki učnega predmeta (slovenščina). To $\mathrm{v}$ osnovi dejansko pomeni enojezično izobraževanje in posledično nasprotje dvojezičnosti, torej čim hitrejša 
vzpostavitev enojezičnosti $\mathrm{v}$ državnem jeziku. Madžarski učenci so bili v narodnostnih oddelkih zaradi kadrovskih razmer deležni manj kakovostnega izobraževanja, saj sta podpora družbe in ugled jezika manjšine zaostajala v primerjavi s slovenščino $\mathrm{v}$ družbi nasploh. Ta model izobraževanja se je v marsičem pokazal kot slab. Namreč, tisti, ki so končali madžarske šole, se niso mogli vpisovati $\mathrm{v}$ slovenske srednje šole zaradi šibkega znanja slovenskega jezika; zaradi železne zavese pa izobraževanja ni bilo mogoče nadaljevati v srednjih šolah na Madžarskem (Varga 2009). Torej ta model dijakom ni omogočal integracije $\mathrm{v}$ srednjih šolah, kjer je pouk potekal $\mathrm{v}$ jeziku večine (dvojezične srednje šole $\mathrm{v}$ Sloveniji takrat ni bilo). Zaradi maloštevilne (madžarske) skupnosti je bilo treba vpeljati drug model.

Pri izbiri nove oblike dvojezičnega izobraževalnega modela sta obe tedanji izobraževalni politiki, manjšinska in večinska, prepoznali, da se ohranitev jezika maloštevilne skupnosti lahko uresniči le s približevanjem $\mathrm{k}$ državnemu jeziku (Kolláth 2009). Hkrati je bila to edina pot $\mathrm{k}$ prenehanju zapiranja $\mathrm{v}$ materni jezik na eni strani in k vzpostavitvi potrebne integracije, brez katere je bila prihodnost nepredstavljiva, na drugi. Tako so leta 1959 šole v Prekmurju začele izvajati dvojezično izobraževanje, uvedba katerega je temeljila na novem zakonu o šolstvu. $V$ današnjem času poteka vse več razprav (največja razprava o tem je bila ob petdesetletnici dvojezičnega šolstva $\mathrm{v}$ zborniku z naslovom Drug z drugim: ob 5o-letnici dvojezičnega šolstva na narodnostno mešanem območju v Prekmurju/Együtt egymásért: a kétnyelvú oktatás 5o. évfordulója a nemzetiségileg vegyesen lakott Muravidéken) o okoliščinah te spremembe. Strokovnjaki s področja šolstva (Nećak Lük 2013), ki so model pripravljali, danes poudarjajo, da se je nov program uvedel brez predhodnih raziskav in analiz ter da učitelji v začetku niso dobili nobenih didaktičnih usmeritev in priporočil, pri reševanju nastalih problemov so se morali zanesti nase ter zgolj na lastno jezikovno in strokovno znanje.

Dvojezično izobraževanje, obvezno za obe narodnosti, je še danes prepoznavno kot dvosmerni model ohranjanja dveh jezikov. Albina Nećak Lük (1989: 11) 
umešča ta izobraževalni model v Mackeyev sistem. Dvosmerni (dva učna jezika; angl. two-way dual/bilingual) model je v tipologiji dvojezičnih izobraževalnih programov označen kot zelo uspešen in učinkovit (Baker 1996; Garcia 1996). V zadnjem času - s širjenjem koncepta in njegovim preoblikovanjem v hipernim - se uporablja termin dvosmerna izobraževalna imerzija (jezikovna kopel; angl. two-way immersion: TWI) (Cathomas 2005: 97). Ugotavljamo, da so osnovni cilji tega modela zelo dobro zastavljeni, to so: 1) prispevati k šolskemu uspehu in doseganju pričakovanj pri študiju madžarskega jezika tistih učencev, katerih prvi jezik ni madžarščina; 2) učencem, pripadnikom večine, pomagati pri usvajanju tujega jezika in razvoju njihove medkulturne ozaveščenosti; 3) zagotoviti jezikovno in etnično enakopravnost večinskih in manjšinskih učencev. Nesporno je torej, da je prekmurski model (imerzije) dvojezičnega izobraževanja eden najučinkovitejših izobraževalnih načinov za doseganje dvojezičnosti. Izvira iz Kanade (Cathomas 2005), razvili so ga za izobraževanje pripadnikov večine $\mathrm{v}$ jeziku manjšine in na ta način se že več kot štirideset let neprekinjeno uspešno izvaja v čedalje več državah sveta. Jezik je učni predmet in učni jezik v enem; učenci se celotno učno snov ali del učne snovi učijo v obeh jezikih, tako je njihova pozornost usmerjena k vsebini učnega predmeta in ne na jezik, jezik se učenci naučijo indirektno, z obravnavanimi učnimi vsebinami. Dvojna/dvosmerna imerzija je kombiniran program, sinteza poučevanja drugega jezika manjšinskih in večinskih učencev. Jezikovni cilj je visoka stopnja aditivne dvojezičnosti tako manjšinskega kot večinskega jezika za obe ciljni skupini, torej učeči jezik se ne sme usvajati na škodo maternega (prvega) jezika. To je neke vrste program ohranjanja, bogatenja jezika, ki se poskuša izogniti negativnim vplivom subtraktivne dvojezičnosti (poljezičnosti), ki jo pogosto izkusijo manjšinski učenci (Cathomas 2005). Kot poglavitni jezikovni cilj programa se v prvi vrsti omenja ohranjanje manjšinskega maternega jezika. Ta model odlično deluje le, če je poučevanje manjšinskega jezika - v našem primeru madžarščine - pri vseh učnih predmetih na visoki stopnji in če se pripadniki manjšine samodejno učijo jezik večine, pripadniki večine pa se 
počutijo dovolj motivirani za sprejemanje in razumevanje jezika in kulture drugega (Cathomas 2005: 113-117).

Prekmurski model ne uteleša le t. i. šolske imerzije, namreč udeleženi ciljni skupini se z jezikom okolja ne srečujeta le v šolskem razredu, ampak se imata načeloma od rojstva priložnost v svojem ožjem in širšem okolju potopiti v drugi jezik in kulturo (prav zaradi tega ne moremo upoštevati drugega jezika kot tuji jezik, ampak enostavno kot drugi jezik, jezik okolja). Bistvo programa ohranjanja jezika je, da dvojezični učitelji poučujejo tako manjšinske kot večinske učence $\mathrm{v}$ maternem in $\mathrm{v}$ drugem jeziku. Cilj tega programa je ob gojenju in ohranjanju obeh kultur vzpostaviti visoko stopnjo funkcionalne dvojezičnosti.

Vprašanje pa je, ali se danes v dvojezičnih šolah ta model dosledno izvaja, kajti model dvosmernega ohranjanja materinščine je smiseln le, če imata skupnost in sama družba od dvojezičnosti korist, če je dopuščen vstop pomembnim in nadpovprečnim medkulturnim in socialnim kompetencam, s katerimi se da pripomoči k mirnemu sobivanju različnih kultur. Iz prakse je namreč razvidno, da se do sedaj ti cilji niso uresničevali popolnoma, da ni idealnega razmerja izobraževalnih jezikov in $\mathrm{v}$ praksi ne pride do uveljavitve zaželenih rezultatov (Nećak Lük 2013; Kolláth 2009). Za uresničitev zaželenih rezultatov je z uvedbo devetletke prišlo do notranje prenove pri strategiji dvojezičnega izobraževanja s t. i. strategijo ena oseba - en jezik kot simultano učenje dveh jezikov v prvem triletju osnovne šole. Ta metoda zahteva v razredu dve osebi, pri čemer ena od njiju dosledno uporablja manjšinski, druga pa večinski jezik, torej učitelja delata po načelu timskega pristopa.

Stroka sicer pravi, da se učenci kmalu navadijo, da vsako osebo naslavljajo v ustreznem jeziku, ker, kot rečeno, ob tem vzorec dvojezičnega pogovora vzpostavljata govorca po načelu ena oseba - en jezik, učencem pri vključevanju v pogovor oziroma pri odločanju o jeziku sporočanja ni treba najprej ovrednotiti elementov govornega položaja. Ker je po zakonskih uredbah obvladovanje 
učnega jezika - tako slovenščine kot madžarščine - učiteljev dvojezičnih šol predpogoj za delovno mesto, učenci dobro vedo, da oba učitelja v razredu razumeta oba jezika, zato se jim ni treba truditi, da bi govorili v obeh. Pri tem se popolnoma strinjamo z naslednjo ugotovitvijo Albine Nećak Lük: »Zavedati se je treba še, da gre za umetne delitve, ki jih ni lahko nadzorovati. Na izvedbeni ravni zahtevajo trajen zavesten napor sodelujočih, ki morajo imeti pred seboj jasno oblikovane kratkoročne in dolgoročne cilje (Nećak Lük 2013: 22). V prvem vzgojno-izobraževalnem obdobju se po načelu ena oseba - en jezik učenci dvojezičnih osnovnih šol opismenjujejo v enem od obeh učnih jezikov, tj. maternem/prvem jeziku, torej v slovenščini ali v madžarščini, drugi učni jezik pa usvajajo kot jezik okolja/drugi jezik. Slovenščino kot drugi jezik imajo tisti, ki se opismenjujejo v madžarščini. Velik problem - poleg že omenjenega - pri tem modelu je tudi ta, da od četrtega razreda naprej usvajajo slovenščino na višji ravni, tj. kot prvi jezik, vsi učenci, tudi tisti, ki so se v obstoječem modelu opismenjevali do četrtega razreda pri pouku prvega jezika, tj. v madžarščini. Učenci, ki so se opismenjevali pri pouku prvega jezika, tj. v slovenščini, pa imajo možnost izbire usvajanja drugega jezika na dveh ravneh: kot prvi jezik oziroma kor drugi jezik. Z uvedbo hkratnega opismenjevanja (HOP) v slovenščini in madžarščini bi ustvarili možnost, da bi lahko učenci že v prvem triletju optimalno razvijali sporazumevalno možnost v obeh jezikih. Ta uvedba že velja in daje možnost in zagotavlja učencem, ki so ustrezno in uravnoteženo dvojezični, da v učnem procesu po vsej vzgojno-izobraževalni vertikali optimalno razvijajo sporazumevalno zmožnost $\mathrm{v}$ obeh jezikih. Namreč, dvojezičnost se dojema kot dodana vrednost bivanja; za obe skupnosti je skupna kultura le dodatek, verodostojnost tega pa nosita oba jezika hkrati. Iz prakse je razvidno, da ima ta model - če se ga dobro izvaja - ogromno prednosti, ima pa tudi zelo pomembne pomanjkljivosti.

\section{POMANJKLJivosti MOdELA}

Kljub omenjenim prizadevanjem in vzorni jezikovni politiki sta ključni 
pomanjkljivosti že od začetka izvajanja nedodelanost didaktične plati modela in neustrezna usposobljenost učiteljev dvojezičnih izobraževalnih ustanov zaradi pomanjkanja možnosti pridobitve ustreznih kompetenc predvsem v madžarskem jeziku (Göncz László 2012). Na skrajnem severovzhodu države imamo madžarščino priznano za uradni in državni jezik, Lendava z okolico, v kateri prebiva največji delež madžarske manjšine, je dvojezična, tj. slovenskomadžarska, kjer so vzgojno-izobraževalne inštitucije dvojezične, nadaljevanje izobraževanja in študij madžarskega jezika in književnosti pa je v Sloveniji mogoč le na Filozofski fakulteti Univerze v Mariboru. Tako je Oddelek za madžarski jezik in književnost FF UM edina možnost za člane madžarske manjšine v RS, da se do- in podiplomsko izobražujejo v madžarskem jeziku. Znanstveno področje Oddelka - študijskih programov in znanstvenoraziskovalnega dela - spada med nacionalne vede (hungaristika) in programi se izvajajo kot program materinščine, ker je to edini način, da se v RS zagotovi celotna vertikala - od vrtca do univerze - izobraževanja avtohtone madžarske skupnosti. Študijski program je edini, ki ponuja v slovenskem visokošolskem prostoru poleg študija tudi dodatno izobraževanje v tem jeziku. Kajti eden izmed ciljev Oddelka za madžarski jezik in književnost je spoznanje, da sta večjezičnost in multikulturnost prihodnost Evrope in modernega človeka ter v duhu tega spoznanja študentom posreduje znanja iz madžarskega jezika in književnosti. Program na eni strani omogoča študentom z madžarskim maternim jezikom študijsko okolje, ki je skladno z njihovimi jezikovnimi pričakovanji, po drugi strani pa je ustvarjeno spodbudno okolje tudi za študente, ki imajo drug materni jezik in želijo pridobiti novo ali izpopolniti že pridobljeno jezikovno znanje. Zato Oddelek v okviru akreditiranega programa ponuja izbirne predmete in lektorske vaje na različnih zahtevnostnih stopnjah študentom z drugih fakultet - predvsem Pedagoške fakultete -, ki prihajajo z dvojezičnega področja in bi se radi tudi tam zaposlili. Študenti razrednega pouka in predšolske vzgoje, ki študirajo na Pedagoški fakulteti UM in se zaposlujejo na dvojezičnih šolah in v vrtcih, so brez ustreznega jezikovno- 
strokovnega znanja in kompetenc iz madžarskega jezika. Na podlagi večletnih izkušenj delovanja na dvojezičnih šolah je Oddelek potrebo po tem predvidel in upošteval že pri pripravi programa za akreditacijo, tako lahko imajo študenti preko univerzitetnega sistema možnost vključevanja v predmete, ki razvijajo njihove jezikovne kompetence. Taka možnost, ki seveda ni obvezna, prinaša dodano vrednost $\mathrm{v}$ dvojezični slovensko-madžarski prostor $\mathrm{z}$ dodatnim jezikovno-kulturno-strokovnim znanjem, s pridobljenimi kompetencami pa pripomore k dvigu izvajanja modela dvojezičnosti tudi v praksi. Na področju pridobivanja jezikovnih kompetenc je velika potreba po notranji zavezanosti učiteljev k programu, stroki in karieri. Torej učitelji razrednega pouka in strokovnih predmetov, če le ni madžarski jezik njihova druga študijska smer, se v RS izobražujejo v slovenskem jeziku. Iz prakse sledi, da imajo ti učitelji znanje madžarščine iz dvojezične osnove in srednje šole (če so se $v$ teh šolah izobraževali). Da ne bi izobraževali učencev in dijakov le z osnovno- in srednješolskim znanjem madžarščine, jim je, kot poudarjeno, med študijem dana ta možnost. Ker gre za zahtevno in pomembno (strokovno)jezikovno spretnost, je ključnega pomena, da se študentje (bodoči učitelji) že med študijem na prvi (pa tudi na drugi) stopnji o tem ustrezno izobrazijo in se usposobijo za to dejavnost.

Poleg tega izvaja Ministrstvo za izobraževanje, znanost in šport na podlagi Zakona o posebnih pravicah italijanske in madžarske narodne skupnosti na področju vzgoje in izobraževanja (Ur. l. RS, št. 35/o1) ter Pravilnika o preizkusu znanja učnega jezika na narodno mešanih območjih pravicah narodnih manjšin (Ur. l. RS, št. 9805) preizkuse znanja učnega jezika za strokovne delavce za opravljanje vzgojno-izobraževalnega dela $\mathrm{v}$ dvojezičnih vrtcih in šolah $\mathrm{v}$ jeziku narodne skupnosti. Navedeni preizkus znanja opravljajo strokovni delavci v dvojezičnih vrtcih in šolah, če ne izpolnjujejo pogoja, ki določa, da strokovni delavec obvlada madžarski jezik kot učni jezik, če je končal program dvojezične srednje šole ali fakultativnega pouka madžarskega jezika na srednji šoli ter fakultativnega pouka madžarskega jezika na visoki ali univerzitetni ravni in si 
je pridobil predpisano izobrazbo v slovenskem in madžarskem jeziku. Prav tako se za strokovne delavce v vrtcih oziroma šolah na narodno mešanih območjih, ki se ustanovijo za dvojezično vzgojo in izobraževanje, zahteva izobrazba, določena z zakoni in drugimi predpisi, tudi opravljen strokovni izpit. Strokovni delavci dvojezičnih vrtcev in šol opravljajo strokovni izpit iz obeh učnih jezikov na različnih ravneh zahtevnosti. $V$ prijavi navedejo, kateri jezik bodo opravljali na osnovni in kateri na višji ravni zahtevnosti.

Kljub omenjenim prizadevanjem in vzorni jezikovni politiki, ki želi spodbujati slovensko-madžarsko dvojezičnost in si prizadeva za enakopravno vključevanje madžarske manjšine na vsa področja življenja v RS, predvsem pa želi spodbujati višjo pisno in bralno kulturo v madžarščini, tj. razvijati model dvojezičnega poučevanja in izobrazbo učiteljev manjšine, je v praksi še vedno prisoten velik manko. Za učitelje dvojezičnih šol je za uspešno izvajanje modela dvojezičnosti pogoj izkazovanje znanja madžarščine na ravni B2, kot jo določa Skupni jezikovni okvir, oziroma na ravni C1 z ustrezno listino. Torej strokovni delavci dvojezičnih šol morajo imeti temu primerno jezikovno znanje $\mathrm{v}$ obeh (slovenskem in madžarskem) jezikih, znati uporabljati dva jezika - ločeno ali skupaj - z različnim namenom, za različne funkcije, na različnih področjih življenja, pri svojem strokovnem predmetu in z različnimi govorci. Bistvo dvojezičnosti je stalna raba dveh jezikov v vsakdanjem življenju posameznikov in ne optimalna enakovredna stopnja dveh jezikov, ker je to nemogoče in se ne zahteva. Glede na to, da se potrebe in raba obeh jezikov zelo razhajajo, je razumljivo, da jezikovna kompetenca $v$ obeh jezikih ne more biti povsem enaka (Rudaš 2012: 81). Brez teh pogojev je izvedba dvojezičnega modela neuspešna in neučinkovita.

\section{DIDAKTIČNI PRIPOMOČKI: STANJE IN AKTUALNI NAČRTI}

Koncepti učenja in poučevanja vplivajo na izbiro didaktičnih pripomočkov v konkretni dvojezični pedagoški praksi. S sodobnimi učnimi oblikami in metodami ter s pestrim izborom učnih pripomočkov omogočamo doživljajsko 
učinkovitejši pouk. V sodobni dvojezični šoli je treba v proces učenja vključevati tudi sodobno tehnologijo: delo v e-učilnici (npr. Moodle), reševanje nalog $\mathrm{v}$ različnih računalniških programih, iskanje in uporabo informacij z različnih spletnih strani itd. Med najpomembnejšimi pripomočki, ki omogočajo učinkovito usvajanje (strokovno)jezikovne strukture in uporabe jezika, pa so dvojezični učbeniki in drugi učni pripomočki - med te nedvomno sodijo dvojezični slovarji. Uporaba slovarja pri tvorjenju besedil izrecno pomaga pri ločevanju različnih pomenov besed (protipomenke, sopomenke, nad- in podpomenke; večpomenskost; enakoizraznost, izrazna podobnost), dalje pa tudi pri pravilnem zapisu, pregibanju, naglaševanju, povezovanju z drugimi besedami ipd. Če gre za dvojezični slovar, vse našteto velja za oba jezika predvsem pa dodatno še primerjalno med obema.

Trenutno so v dvojezičnih šolah v Prekmurju na voljo naslednji dvojezični slovensko-madžarski in madžarsko-slovenski slovarji:

- Online Szlovén Magyar Szótár. Dostopno prek: http://www.etranslator.ro/hu/szloven-magyar-online-szotar.php.

- Slovensko-madžarski slovar (Advanced), Szlovén-magyar szótár (Advanced) - Lingea Kft. Dostopno prek: https://szotar.lingea.hu/szlovenmagyar.

- Linguee - Magyar-Szlovén Szótár- és Fordításkereső. Dostopno prek: http://www.linguee.hu/magyar-szlov\%C3\%Agn.

- Magyar-szlovén szótár. Dostopno prek: http://szotar.woxikon.hu/hu-sl-c.

- Jože Hradil (1998). Madžarsko-slovenski slovar/Magyar-szlovén szótár. Murska Sobota: Pomurska založba.

- Jože Hradil (1996). Slovensko-madžarski slovar/Szlovén-magyar szótár. Ljubljana: DZS. Dostopno prek: http://www.krog-znaksp.si/slovensko.php/slo-hun-slovar-szotar.

- Szlovén-magyar

szótár.

Dostopno

prek:

http://www.prevajalnik.net/slovensko-madzarski-slovar. 
- Elizabeta Bernjak (1995). Madžarsko-slovenski slovensko-madžarski slovar/Magyar-szlovén szlovén-magyar szótár. Ljubljana: Cankarjeva založba.

- Marija Kozar/Kozár Mária (1996). Etnološki slovar slovencev na Madžarskem/A magyarországi szlovének néprajzi szótára. Monošter Szombathely: Zveza Slovencev na Madžarskem - Savaria Múzeum.

- Ferenc Mukics /Francek Mukič (1993). Magyar-szlovén frazeológiai szótár/Madžarsko-slovenski frazeološki slovar. Szombathely: Zveza Slovencev na Madžarskem.

- Nives Kuhar (2005). Slovar ekonomskih izrazov v slovenščini in madžarščini. Toro.

- Sándor Szúnyogh 1990. Slovensko-madžarski slovar družbenopolitične terminologije/Szlovén-magyar társadalmi-politikai müszótár. Murska Sobota: Zavod za časopisno in radijsko dejavnost.

- Vili Vrhovec (1990). Madžarsko/slovensko-Slovensko/madžarsko (Priročni slovarček). Ljubljana: Državna založba Slovenije.

Našteti dvojezični slovarji imajo za namene dvojezičnega pouka več pomanjkljivosti, glavne so predvsem zastarelost tako glede vsebine (slovarji večjega obsega so stari že 15-2o let) kot medija (temeljni slovarji so večinoma dostopni samo $\mathrm{v}$ tiskani obliki), majhen obseg geslovnika in le delna naravnanost na potrebe izobraževalnega sistema (več gl. v Bálint Čeh in Kosem v tej številki).

Primanjkljaj šolsko usmerjenih slovarskih virov in sodobnih didaktičnih pripomočkov ter posledično $\mathrm{z}$ njimi povezanih kompetenc učiteljev $\mathrm{v}$ dvojezičnih šolah je po približno 50 letih prvič skušal sistematično nasloviti projekt iz leta 2012, ki sta ga financirala Evropski socialni sklad ter Ministrstvo za šolstvo in šport Republike Slovenije, z naslovom E-kompetence učiteljev $v$ dvojezičnih šolah. Temeljni cilj projekta je bil »dvig ravni e-kompetenc učiteljev v madžarskem jeziku v dvojezičnih šolah (slovensko-madžarskih) v Prekmurju, 
posledično pa tudi dvig konkurenčnosti znanja otrok, ki obiskujejo dvojezične vzgojno-izobraževalne zavode na narodnostno mešanem območju severovzhodne Slovenije«. Posredni cilji projekta pa so bili »dvig informacijske pismenosti v dvojezičnih vzgojno-izobraževalnih zavodih, večja uporaba že obstoječe informacijsko-komunikacijske tehnologije, e-storitev in e-vsebin, boljša izrabljenost didaktične in splošne programske opreme, večja izmenjava dobrih praks med učitelji in večje povezovanje dvojezičnih šol med sabo ter z okoljem «.2 Zato so se v okviru projekta izvajale aktivnosti, kot so razvijanje jezikovnih e-kompetenc v madžarskem jeziku, razvoj e-gradiv, razvijanje in nadgradnja poučevanja madžarščine kot drugega jezika z uporabo IKT ter oblike motivacij za spoznavanje madžarskega jezika in kulture z IKT.

Nosilec projekta je bil Zavod za kulturo madžarske narodnosti - Magyar Nemzetiségi Müvelődési Intézet, v njem pa je sodelovalo dvanajst ustanov. 3 Ključne naloge sodelujočih partnerjev so bile: priprava e-vsebin in spletnih učilnic, izdelava spletnih slovarjev, izdelava gradiv za diferenciacijo pouka pri predmetu Madžarščina 2, priprava metodologije poučevanja dvojezičnega pouka - strategija poučevanja v dvojezičnem modelu izobraževanja, izdelava priročnika za učitelje, priprava učnih priprav in zbirk nalog ter tehnična vzpostavitev spletnih učilnic in vsebin na portalu SIO. Pomemben prispevek v projektu je metodološki priročnik (Priročnik za učitelje dvojezičnih šol v Prekmurju - Kézikönyv a muravidéki kétnyelvű iskolák pedagógusai számára).

\footnotetext{
2 http://.e-kompetencia.si/index.php/o-projektu-o-projektu/splosno-o-projektu-a-projektrol 3 Dvojezična osnovna šola Lendava I. - I. Számú Lendvai Kétnyelvü Általános Iskola, Dvojezična osnovna šola Lendava II. - II. Számú Lendvai Kétnyelvủ Általános Iskola, Dvojezična osnovna šola Genterovci - Göntérházi Kétnyelvű Általános Iskola, Dvojezična osnovna šola Dobrovnik - Kétnyelvü Általános Iskola Dobronak, Dvojezična osnovna šola Prosenjakovci - Kétnyelvü Általános Iskola Pártosfalva, Dvojezična srednja šola Lendava Kétnyelvű Középiskola Lendva, Vrtec Lendava - Lendvai Óvoda; Inštitut za narodnostna vprašanja, Filozofska fakulteta Univerze v Mariboru, Zavod Antona Martina Slomška; Pomurska madžarska samoupravna narodna skupnost - Muravidéki Magyar Önkormányzati Nemezti Közösség in Zavod Republike Slovenije za šolstvo. (opomba se nadaljuje na naslednji strani)
} 
Ta zajema temeljna znanja, ki so učiteljem dvojezičnih šol v pomoč pri opravljanju vzgojno-izobraževalnega dela s poudarkom, da dvojezične šole »ne le, da morajo biti konkurenčne s slovenskimi, ampak morajo po svoji naravi ustvariti dodano vrednost, razviti v mladih jezikovno znanje in tolerantnost, ki je potrebna za sožitje, za zdravo udejstvovanje na dvojezičnem območju, za sposobnost živeti v multikulturni skupnosti«.4 Nepogrešljiv segment projekta je bila tudi priprava e-slovarjev oziroma e-zbirke izrazov s petnajstih strokovnih področij (fizika, geografija, strojništvo, poslovna komunikacija, književnost, kemija, likovna umetnost, knjižničarstvo, ekonomija, matematika, jezikoslovje, otroci s posebnami potrebami, šport, zgodovina in glasba). E-zbirke izrazov so prosto dostopne na http://eslovar.datadev.si/select.php.

Drugi projekt, ki problematiko pomanjkanja sodobnih slovensko-madžarskih in madžarsko-slovenskih slovarjev naslavlja še bolj celostno in neposredno, pa je ciljni raziskovalni projekt Koncept madžarsko-slovenskega slovarja: od jezikovnega vira do uporabnika (KOMASS, projekt V6-1509, 2015-2018), $5 \mathrm{ki}$ ga v letih 2015-2018 financirata Javna agencija za raziskovalno dejavnost Republike Slovenije in Ministrstvo za izobraževanje, znanost in šport Republike Slovenije, izvajajo pa Filozofska fakulteta Univerze v Ljubljani (vodilni partner), Filozofska fakulteta Univerze v Mariboru in Inštitut za narodnostna vprašanja.

Cilj projekta je izdelati koncept, pa tudi že prva gesla, velikega slovenskomadžarskega slovarja, ki bi po eni strani zadostil potrebam širše skupnosti, po drugi pa bi vseboval tudi slovarske vsebine, ki so relevantne za dvojezično izobraževanje (predvsem za učitelje, ki tako izobraževanje izvajajo). Slovar bo naslavljal v literaturi večkrat izpostavljene težave učiteljev, katerih materni jezik je slovenščina, izobražujejo pa v madžarskem jeziku (npr. Gomivnik

\footnotetext{
4 http://.e-kompetencia.si/images/epublikacije/prirocnik/e-

kompetencia_modszertan_prirocnik_20131024_splet_kazalo.pdf

5 http://www.cjvt.si/komass/
} 
Thuma idr. 2010). Največkrat omenjene težave se nanašajo na jezikovno produkcijo (manj na recepcijo), npr. slab besedni zaklad, povezan s strokovno terminologijo v šolah, pa tudi s pisnim izražanjem nasploh, slabo poznavanje pravopisa in nepravilno izgovarjanje besed. Uporabniške študije (več gl. Kosem in Kovacs v tej številki) so pokazale, da se učitelji pri reševanju teh težav opirajo na enojezične in dvojezične vire, kot so slovarji, pravopisi ipd.

Ključne lastnosti, ki jih obstoječi slovensko-madžarski in madžarsko-slovenski slovarji nimajo oz. jih imajo v zelo majhni meri, novi slovar pa jih bo nujno moral vsebovati, so torej naravnanost na jezikovno produkcijo, korpusna zasnovanost in izkoriščanje prednosti digitalnih medijev. ${ }^{6}$ Gre za vključevanje informacij, kot so (celostavčni) korpusni zgledi, kolokacije, posnetki izgovarjave ipd. (več gl. Bálint Čeh in Kosem v tej številki). Ob tem ni zanemarjiv tudi širši učinek projekta: pri novem slovensko-madžarskem slovarju bo izdelana podatkovna baza $\mathrm{v}$ formatu, ki omogoča povezljivost oz. združljivost s sorodnimi slovarskimi bazami in je uporabna tudi za jezikovne tehnologije (npr. strojno prevajanje). Sodobna leksikografska praksa (gl. Gorjanc idr. 2015) namreč kaže, da lahko dobro strukturirane slovarske baze, te pogosto vsebujejo še dodatne podatke, ki v slovar niso vključeni, znatno pripomorejo k razvoju drugih jezikovnih virov in orodij, tako šolsko naravnanih kot tistih za splošno rabo.

\section{ZAKLJUČEK}

Madžarski jezik je regionalni uradni jezik, eden uradnih jezikov Evropske unije in ima na narodnostno mešanem območju Prekmurja poseben status; ${ }^{7} \mathrm{v}$ okviru dvojezičnega šolskega izobraževanja se učenci tako slovenske (ali druge) kot

\footnotetext{
${ }^{6} \mathrm{~V}$ nasprotju s tem so obstoječi slovarji naravnani predvsem na recepcijo, kar pomeni, da v paru slovenski + madžarski jezik (v tem zaporedju) nudijo precej več informacij madžarskemu uporabniku pri razumevanju slovenskih besed kot pa slovenskemu uporabniku pri uporabi madžarščine.

7 11. in 64. člen Ustave RS. Dostopno: http://.pisrs.si/Pis.web/pregledPredpisa?id=USTA1
} 
madžarske narodnosti srečujejo $\mathrm{z}$ obema jezikoma - slovenskim in madžarskim. V dvojezičnih šolah je madžarski jezik prvi jezik učencev madžarske narodnosti in drugi jezik učencev slovenske ali druge narodnosti. Uresničevanje ciljev v dvojezičnih šolah temelji na razvijanju kompetenc $\mathrm{v}$ obeh jezikih.

Model dvojezične vzgoje in izobraževanja sodi med dvosmerne modele ohranjanja dveh jezikov in kultur. Ob spoznavanju in razumevanju dveh kultur ter dveh družbenih odnosov učenci razvijajo pozitivna stališča do kulturne različnosti in razvijajo medkulturne odnose. $V$ okviru šolskih predmetov učimo strokovno terminologijo $\mathrm{v}$ obeh jezikih ter vzgajamo govorce, ki tako pozitivno doživljajo jezikovno in kulturno različnost na narodnostno mešanem območju Prekmurja.

Nekatere sociolingvistične raziskave govorijo o tem, da je v neuravnoteženem družbenem položaju ohranjanje jezika manjšine odvisno od relativno stabilnega razmejevanja funkcij jezikov $\mathrm{v}$ javnem sporazumevanju (diglosija). Podoben argument je podan za šolsko okolje, ko naj bi z jezikovno organizacijo pouka vzpostavili ustrezno razmejitev funkcij obeh jezikov in tako okrepili položaj jezika manjšine. (Nećak Lük 2013: 22)

V zadnjem času se stanje na področju opremljenosti dvojezičnega izobraževanja v Prekmurju z didaktičnimi pripomočki, kakršna so npr. e-gradiva in e-zbirke terminoloških izrazov, izboljšuje. Posledično se izboljšujejo tudi digitalne in jezikovne kompetence učiteljev. Dobrodošle so tudi spodbude k nadaljnjim raziskavam o učinkovitosti dvojezičnega modela izobraževanja v Prekmurju (gl. npr. nedavni razpis Javne agencije za raziskovalno dejavnost Republike Slovenije za projekte ciljnega raziskovalnega programa s temo Uresničevanje ciljev dvojezične vzgoje in izobraževanja na narodnostno mešanem območju $v$ Prekmurju). Taka kombinacija aplikativnih in temeljnih ciljno usmerjenih raziskovalnih projektov lahko zagotovo pripelje do še boljše kakovosti dvojezičnega učnega procesa. Zelo pomembno pa je tudi, da se v projekte, kakršna sta (bila) E-kompetence učiteljev $v$ dvojezičnih šolah in KOMASS, 
povežejo vsi deležniki, ki si želijo učinkovitega, prijaznega ter uspešnega jezikovnega sobivanja: od šol in učiteljev, ki dvojezično izobraževanje izvajajo, univerz, ki usposabljajo bodoče učitelje, do raziskovalnih ustanov, ki preučujejo učinkovitost učnega modela, zanj pripravljajo učne pripomočke in iščejo možnosti za njegovo izboljšavo.

\section{LITERATURA}

Baker, C. (1996): Foundations of Bilingual Education and Bilingualism. Clevedon: Multilingual Matters.

Bartha Cs. (2003): A kisebbségi nyelvek megőrzésének lehetőségei és az oktatás. O. Nádor in L. Szarka (ur.): Nyelvi jogok, kisebbségek, nyelvpolitika Kelet-Közép-Európában: 56-75. Budapest: Akadémiai Kiadó.

Bartha, Cs. (1999): A kétnyelvúség alapkérdései. Budapest: Nemzeti Tankönyvkiadó.

Bartha, Cs. (2004): Kétnyelvűség, oktatás, kétnyelvű oktatás és kisebbségek. A hetven éves Szépe Györgynek. Educatio 2004 (4): 761-775.

Cathomas, R. M. (2005): Schule und Zweisprachigkeit. Münster / New York / München / Berlin: Waxmann.

García, O. (1996): Bilingual Education. V F. Coulmas (ur.): The Handbook of Sociolinguistics: 40-420. Oxford, Cambridge: Blackwell.

Gomivnik Thuma, V., Milekšič, V., Pisnjak, M., Kumer, I., in László, H. (2010): Spremljanje pouka $v$ dvojezičnih osnovnih šolah na narodno mešanem območju Prekmurja. Poročilo, poslano Strokovnemu svetu RS za splošno izobraževanje ter Svetu za evalvacije in kakovost.

Göncz, Lajos (2004): A vajdasági magyarság kétnyelvúsége. Szabadka: MTT Könyvtár 8. 
Göncz, László (2012): A magyar nemzeti közösség nyelvi jogai és nyelvhasználata Szlovéniában. V K. Eplényi in Z. Kántor (ur.): Térvesztés és határtalanítás. A magyar nyelvpolitika 21. századi kihívásai: 103-121. Budapest: Nemzetpolitikai Kutatóintézet.

Gorjanc, V., Gantar, P., Kosem, I., in Krek, S., ur. (2015): Slovar sodobne slovenščine: problemi in rešitve. Ljubljana: Univerza v Ljubljani, Filozofska fakulteta.

Iser, W. (2004): Az értelmezés világa. Budapest: Gondolat Kiadó-ELTE Összehasonlító Irodalomtudományi Tanszék.

Kolláth, A., ur. (2009): A muravidéki kétnyelvü oktatás fél évszázada. Bielsko-Biała, Budapest, Kansas, Maribor, Praha: ZORA 68.

Kolláth, A. (2013): Nekaj misli o modelih dvojezičnega izobraževanja. V Mária Pisnjak (ur.): Priročnik za učitelje dvojezičnih šol v Prekmurju: 535657. Lendava: Zavod za kulturo madžarske narodnost / Lendva: Magyar Nemzetiségi Múvelődési Intézet.

Lanstyák, I. (2005): A kétnyelvü oktatás esélyei és veszélyei Szlovákiában. V É. Ring (ur.): Felzárkózás vagy bezárkózás? A többnyelvú oktatás elönyei, veszélyei a kisebbségi közösségek életében: 43-73. Budapest: Európai összehasonlító Kisebbségkutatások Közalapítvány.

Nećak Lük, A. (1989): Vzgoja in izobraževanje v večjezičnih okoljih. Motivacija za učenje maternega in drugega jezika $v$ dvojezični osnovni šoli v Prekmurju (II. del). Ljubljana: Pedagoški inštitut pri Univerzi Edvarda Kardelja v Ljubljani.

Nećak Lük, A. (2013): Metodologija jezikovne organizacije dvojezičnega pouka. V Priročnik za učiteljev dvojezičnih šol v Prekmurju. Dostopno prek: http://.ekompetencia.si/images/epublikacije/prirocnik/ekompetencia_modszertan_prirocnik_20 131024_splet_kazalo.pdf (20.10. 2017). 
Rudaš, J. (2012): Kulturális intarziák/Kulturne intarzije. Pilisvörösvár: Muravidéki Baráti Kör Kulturális Egyesület.

Skutnabb-Kangas, T. (1990): Language, Literacy and Minorities. London: A Minorities Rights Group Report.

Skutnabb-Kangas, T. (1997): Nyelv, oktatás és a kisebbségek. Budapest: Teleki László Alapítvány.

Varga, J. (2009): A kétnyelvú oktatás Szlovéniában. Dunaharaszti: NAP Alapítvány.

Herman, J., in Sabo, T., ur. (2010). Drug z drugim: ob 5o-letnici dvojezičnega šolstva na narodnostno mešanem območju $v$ Prekmurju = Együtt egymásért: a kétnyelvú oktatás 50. évfordulója a nemzetiségileg vegyesen lakott Muravidéken. Lendava: Dvojezični vzgojnoizobraževalni zavodi na narodnostno mešanem območju v Prekmurju / Lendva: A kétnyelvű nevelő-oktató intézetek a nemzetiségileg vegyesen lakott Muravidéken. 


\section{BILINGUAL EDUCATION MODEL IN \\ PREKMURJE, AND THE DICTIONARY AS A TEACHING AID}

The model of bilingual education is one of the two-way models of preserving two languages and cultures. This paper describes the successful implementation of a bilingual education process, with a short developmental span and an emphasis on the key deficiencies of the model. By getting to know two cultures and two social relationships and by understanding them, pupils develop a positive attitude to cultural diversity as well as intercultural relationships. Within the framework of school subjects, we teach professional terminology in both languages and thus educate speakers in a way that they experience linguistic and cultural diversity in the ethnically mixed area of Prekmurje.

The model of the two-way preservation of the mother tongue makes sense only if the community and the society benefit from bilingualism, and if important and above-average intercultural and social competences that contribute to peaceful coexistence of different cultures are allowed access. Practice shows that so far these goals have not been fully implemented, that there is no ideal relationship between the languages of instruction and that the desired results are not implemented.

We have found that there are two shortcomings in this respect: the incomplete didactic aspect and the inadequate competence of teachers in bilingual educational institutions owing to the lack of possibility of acquiring the appropriate competences, particularly in the Hungarian language. Among the most important means for the efficiency of the language structure acquisition and language use are bilingual textbooks and other teaching aids. Based on these findings, this paper presents cognitive and other skills that enable the integration of a bilingual dictionary into the teaching process. As this is a demanding and important skill, it is crucial that teachers and pupils are trained in this activity. The dictionary as a didactic tool is not merely a means of information but also a basis for the development of skills at various language levels. This is undoubtedly 
true also for modern, useful dictionaries, designed with innovative lexical approaches and with all the advantages of electronic media in combination with other didactic tools and technologies. We also present two important projects that have improved the situation in bilingual education by developing dictionaries and e-materials, and providing teachers with skills for using them in class. We conclude that teachers and students in bilingual education in Prekmurje are now better equipped for their work. Also, a recently published call for research projects into bilingual education in Slovenia indicates that more improvements to the bilingual education model in Prekmurje can be expected.

Key words: bilingual education in the Prekmurje region, bilingual dictionary, mother tongue, second language, language competences

To delo je ponujeno pod licenco Creative Commons: Priznanje avtorstvaDeljenje pod enakimi pogoji 4.o Mednarodna.

This work is licensed under the Creative Commons Attribution-ShareAlike 4.0 International.

https://creativecommons.org/licenses/by-sa/4.o/

(c) (i) () () 